\title{
Sonic Hedgehog Guides Axons via Zipcode Binding Protein 1-Mediated Local Translation
}

\author{
Léa Lepelletier, ${ }^{1}$ Sébastien D. Langlois, ${ }^{1,2}$ Christopher B. Kent, ${ }^{1}$ CKristy Welshhans, ${ }^{3,4}$ Steves Morin, ${ }^{1}$ \\ Gary J. Bassell, ${ }^{5,6}$ Patricia T. Yam, ${ }^{1}$ and ${ }^{-}$Frédéric Charron ${ }^{1,2,7,8}$ \\ ${ }^{1}$ Molecular Biology of Neural Development, Institut de Recherches Cliniques de Montréal, Montreal, Quebec, Canada H2W 1R7, 2Division of Experimental \\ Medicine, McGill University, Montreal, Quebec, Canada H3A 1A3, ${ }^{3}$ Department of Biological Sciences and ${ }^{4}$ School of Biomedical Sciences, Kent State \\ University, Kent, Ohio 44242, ${ }^{5}$ Department of Cell Biology and ${ }^{6}$ Department of Neurology, Emory University School of Medicine, Atlanta, Georgia 30322, \\ ${ }^{7}$ Department of Anatomy and Cell Biology, Department of Biology, McGill University, Quebec, Canada H3A 2B2, and ${ }^{8}$ Department of Medicine, University \\ of Montreal, Montreal, Quebec, Canada H3T 1J4
}

Sonic hedgehog (Shh) attracts spinal cord commissural axons toward the floorplate. How Shh elicits changes in the growth cone cytoskeleton that drive growth cone turning is unknown. We find that the turning of rat commissural axons up a Shh gradient requires protein synthesis. In particular, Shh stimulation increases $\beta$-actin protein at the growth cone even when the cell bodies have been removed. Therefore, Shh induces the local translation of $\beta$-actin at the growth cone. We hypothesized that this requires zipcode binding protein 1 (ZBP1), an mRNA-binding protein that transports $\beta$-actin mRNA and releases it for local translation upon phosphorylation. We found that Shh stimulation increases phospho-ZBP1 levels in the growth cone. Disruption of ZBP1 phosphorylation in vitro abolished the turning of commissural axons toward a Shh gradient. Disruption of ZBP1 function in vivo in mouse and chick resulted in commissural axon guidance errors. Therefore, ZBP1 is required for Shh to guide commissural axons. This identifies ZBP1 as a new mediator of noncanonical Shh signaling in axon guidance.

Key words: axon guidance; local translation; Sonic hedgehog; ZBP1

Significance Statement

Sonic hedgehog (Shh) guides axons via a noncanonical signaling pathway that is distinct from the canonical Hedgehog signaling pathway that specifies cell fate and morphogenesis. Axon guidance is driven by changes in the growth cone in response to gradients of guidance molecules. Little is known about the molecular mechanism of how Shh orchestrates changes in the growth cone cytoskeleton that are required for growth cone turning. Here, we show that the guidance of axons by Shh requires protein synthesis. Zipcode binding protein 1 (ZBP1) is an mRNA-binding protein that regulates the local translation of proteins, including actin, in the growth cone. We demonstrate that ZBP1 is required for Shh-mediated axon guidance, identifying a new member of the noncanonical Shh signaling pathway.

\section{Introduction}

During nervous system development, axons are guided by attractive and repulsive guidance cues present in the extracellular environment as they migrate to their appropriate targets. One such guidance cue is Sonic hedgehog (Shh), which guides commissural axons, retinal ganglion cells, and midbrain dopaminergic neu-

Received Sept. 20, 2016; revised Dec. 15, 2016; accepted Dec. 27, 2016.

Author contributions: G.J.B., P.T.Y., and F.C. designed research; L.L., S.D.L., C.B.K., K.W., and S.M. performed research; L.L., S.D.L., C.B.K., K.W., P.T.Y., and F.C. analyzed data; P.T.Y. and F.C. wrote the paper

This work was supported by the Canadian Institutes of Health Research (CIHR), the Fonds de Recherche du Québec-Santé (FRQS), and the Canada Foundation for Innovation (CFI). F.C. holds the Canada Research Chair in Developmental Neurobiology. The 4D7 antibody was obtained from the Developmental Studies Hybridoma Bank developed under the auspices of the National Institute of Child Health and Human Development and maintained by The University of lowa. We thank Cornelia Zorca for comments on the manuscript and Shirin Makihara, Julien Ferent, and Cornelia Zorca for technical assistance. rons (Yam and Charron, 2013). Shh also acts in the nervous system as a morphogen to specify cell fate through a canonical signaling pathway that leads to Gli-dependent transcription of target genes (Dessaud et al., 2008). Importantly, the signaling pathway used by Shh to guide axons is distinct from the canonical signaling pathway used to specify cell fate. Shh mediates axon guidance via a noncanonical transcription-independent pathway (Yam et al., 2009).

\footnotetext{
The authors declare no competing financial interests.
}

Correspondence should be addressed to either Patricia Yam or Frédéric Charron, Molecular Biology of Neural Development, Institut de Recherches Cliniques de Montréal (IRCM), 110 Pine Ave West, Montreal, Quebec, Canada H2W 1R7. E-mail: patricia.yam@ircm.qc.ca or Frederic.Charron@ircm.qc.ca.

DOI:10.1523/JNEUROSCI.3016-16.2016

Copyright $\odot 2017$ the authors $\quad 0270-6474 / 17 / 371685-11 \$ 15.00 / 0$ 
Commissural neurons are located in the dorsal part of the developing spinal cord and send their axons ventrally toward the floorplate. Shh-mediated attraction of commissural axons requires the receptor Boc (Okada et al., 2006) and the 7-pass transmembrane protein Smo (Charron et al., 2003; Yam et al., 2009). Shh activates Src family kinases (SFKs) in an Smo-dependent manner to guide commissural axons (Yam et al., 2009). Shh induces commissural axon growth cone turning within $10 \mathrm{~min}$ (Yam et al., 2009), suggesting that rapid changes occurring locally at the growth cone underlie axon guidance by Shh. These rapid changes in growth cone dynamics could result from local translation. Translation of mRNAs in the growth cone is a much faster way to change growth cone protein levels than axonal transport of proteins from the cell body (Shigeoka et al., 2013). Other axon guidance cues, such as Netrin-1 and Sema3A, have been shown to stimulate local protein synthesis in the growth cone and this local protein synthesis is required for the growth cone to respond to these guidance cues in vitro (Campbell and Holt, 2001).

One important locally translated protein for growth cone turning in vitro is $\beta$-actin. Local translation of $\beta$-actin in growth cones occurs in response to Netrin-1 and BDNF and is required for the in vitro turning response to these guidance cues (Leung et al., 2006; Yao et al., 2006). Local translation of $\beta$-actin depends on zipcode binding protein 1 (ZBP1, also known as Vg1RBP in Xenopus and Igf2bp1 in humans; Zhang et al., 2001; Leung et al., 2006; Welshhans and Bassell, 2011), which binds a 54-nucleotide cis-element in the $3^{\prime}$-UTR of $\beta$-actin mRNA known as the zipcode (Ross et al., 1997). ZBP1 binds to its cargo mRNAs to form a ribonucleoprotein complex, which is then transported along microtubules to distal locations in the cell (Zhang et al., 1999; Xing and Bassell, 2013). The zipcode sequence of $\beta$-actin mRNA is necessary for ZBP1 to bind $\beta$-actin mRNA and transport it to the growth cone (Zhang et al., 2001). ZBP1 binding to the $3^{\prime}$-UTR represses translation of $\beta$-actin mRNA during transport (Hüttelmaier et al., 2005). Translation is activated at the target location, such as the growth cone, by Src-mediated phosphorylation of ZBP1 at Tyr396, which releases $\beta$-actin mRNA from ZBP1 for local translation (Hüttelmaier et al., 2005; Sasaki et al., 2010; Wu et al., 2015). Although a role for ZBP1 in axon arborization has been shown (Kalous et al., 2014), it is not known whether ZBP1 has a function in axon guidance in vivo.

We have demonstrated that Shh-mediated axon guidance does not require transcription (Yam et al., 2009). However, we have yet to determine whether it requires translation. In this study, we show that Shh-mediated axon guidance requires translation. Furthermore, we show that one protein locally synthesized at the growth cone in response to Shh is $\beta$-actin. Shh stimulation also leads to phosphorylation of ZBP1 in the growth cone. Finally, we demonstrate that ZBP1 activity is required for Shhmediated axon guidance in vitro and in vivo, thus identifying ZBP1 as a new member of the noncanonical Shh signaling pathway. Together, our findings link Shh activity to local changes in the cytoskeleton of the growth cone. Importantly, we also demonstrate an in vivo axon guidance phenotype due to disruption of ZBP1 function.

\section{Materials and Methods}

Plasmids. WT ZBP1 and ZBP1 Y396F constructs were made by subcloning the coding region from the mCherry-ZBP1-wt and mCherry-ZBP1Y396F constructs (Welshhans and Bassell, 2011) into the pCAGGS vector. The GFP construct used was pCAGGS-EGFP.

Animals. All animal work was performed in accordance with the Canadian Council on Animal Care Guidelines and approved by the Institut de Recherches Cliniques de Montréal Animal Care Committee. Staged pregnant female Sprague Dawley rats were obtained from Charles River Laboratories. $\mathrm{Zbp1}^{-1-}\left(\operatorname{Imp} 1^{-1-}, \operatorname{Igf2bp1^{\mathrm {Gt}(\mathrm {OST}33739)\mathrm {Lex}-})}\right.$ mice have been described previously (Hansen et al., 2004) and were raised at the Emory University School of Medicine. All experimental procedures were approved by Emory University's Institutional Animal Care and Use Committee and were in accordance with the federal Animal Welfare Act PL 89-544 (1966) and subsequent amendments and the documents entitled Guide for the Care and Use of Laboratory Animals and Public Health Service Policy on Humane Care and Use of Laboratory Animals. Embryonic day 0 (E0) was defined as midnight of the night before a plug was found. Tissue from embryos of either sex was used for experiments.

Reagents and antibodies. Monoclonal mouse IgM anti-Tagl antibody (4D7; RRID:AB_2315433) was obtained from the Developmental Studies Hybridoma Bank and used at 1:200. Polyclonal guinea pig anti-ZBP1 and polyclonal rabbit anti-phospho-ZBP1 (Sasaki et al., 2010) were used at 1:200 for immunostaining and 1:1000 for Western blotting. Mouse anti- $\beta$-actin (Sigma-Aldrich; RRID:AB_476744) was used at 1:200 for immunostaining. PP2 and PP3 were from Calbiochem.

Dissociated commissural neuron culture. Dissociated commissural neuron cultures were prepared from the dorsal fifth of E13 rat neural tubes as described previously (Yam et al., 2009, 2012; Langlois et al., 2010). They were plated in Neurobasal medium supplemented with $10 \%$ heatinactivated FBS and $2 \mathrm{~mm}$ L-glutamine (Invitrogen). After $\sim 21 \mathrm{~h}$, the medium was changed to Neurobasal supplemented with 2\% B27 and 2 mM L-glutamine. Dissociated commissural neuron cultures were used for experiments at $2 \mathrm{~d}$ in vitro (DIV). For Dunn chamber experiments, commissural neurons were plated at 150000 cells/well in a six-well plate on acid-washed PLL-coated $18 \mathrm{~mm}$ square \#3D coverslips (Fisher Scientific). For immunofluorescence staining, commissural neurons were plated at 35,000 cells/well in a 24-well plate on acid-washed PLL-coated $12 \mathrm{~mm}$ round \#1D coverslips.

Electroporation of commissural neurons. Neurons were electroporated with the Amaxa 96-well Shuttle using the P3 Primary Cell 96-well Nucleofector Kit (Lonza) according to the manufacturer's instructions. For each electroporation in one well of a 96-well Nucleofector plate, $3-5 \times 10^{5}$ cells and $0.6 \mu \mathrm{g}$ of plasmid DNA were used. The electroporation was performed with the 96-DC-104 program.

Dunn chamber axon guidance assay and analysis. Dunn chamber axon guidance assay, imaging, and analysis were performed as described previously (Yam et al., 2009). Briefly, commissural neurons were grown on poly-L-lysine $(100 \mu \mathrm{g} / \mathrm{ml})$-coated square \#3D coverslips at low density and then assembled in a Dunn chamber with or without drug addition. Gradients were generated in the Dunn chamber with 0.1 or $0.4 \mu \mathrm{g} / \mathrm{ml}$ recombinant human Shh (C24II; R\&D Systems) or buffer containing BSA (the vehicle for Shh) in the outer well. After Dunn chamber assembly, time-lapse phase contrast images were acquired for a minimum of $2 \mathrm{~h}$ at $37^{\circ} \mathrm{C}$ on a Leica DMIRE2 inverted microscope using a $20 \times$ Fluotar objective. The angle turned was defined as the angle between the original direction of the axon and a straight line connecting the base of the growth cone from the first to the last time point of the assay period. Axons that were already growing parallel toward the Shh gradient (i.e., those axons with initial angles $<20^{\circ}$ with respect to the gradient) were excluded from the analysis because they were already following the high Shh concentration gradient.

Immunostaining and microscopy. For immunostaining of spinal cord cross-sections, mouse embryos were collected at E11.5 and rat embryos at E13.5 (the equivalent stage to mouse embryos), fixed in 4\% PFA for $2-3 \mathrm{~h}$ at room temperature, transferred to $30 \%$ sucrose at $4^{\circ} \mathrm{C}$ overnight, then embedded in optimal cutting temperature medium and frozen. Next, $12 \mu \mathrm{m}$ sections were cut.

For immunostaining of dissociated commissural neuron cultures, cells were fixed with $4 \%$ PFA for $15 \mathrm{~min}$ and then washed in PBS. Samples were then blocked with PBS $+10 \%$ goat serum $+0.1 \%$ Triton X-100. Primary antibodies were incubated with the samples overnight at $4^{\circ} \mathrm{C}$. Secondary antibodies were added for $1 \mathrm{~h}$ at room temperature. DAPI was used to stain nuclei. Coverslips were mounted in Mowiol (Sigma-Aldrich).

Immunostained neurons were imaged on a Leica DM6000 or DMIRE2 microscope with a $63 \times$ numerical aperture 1.4 objective and a Ham- 
a
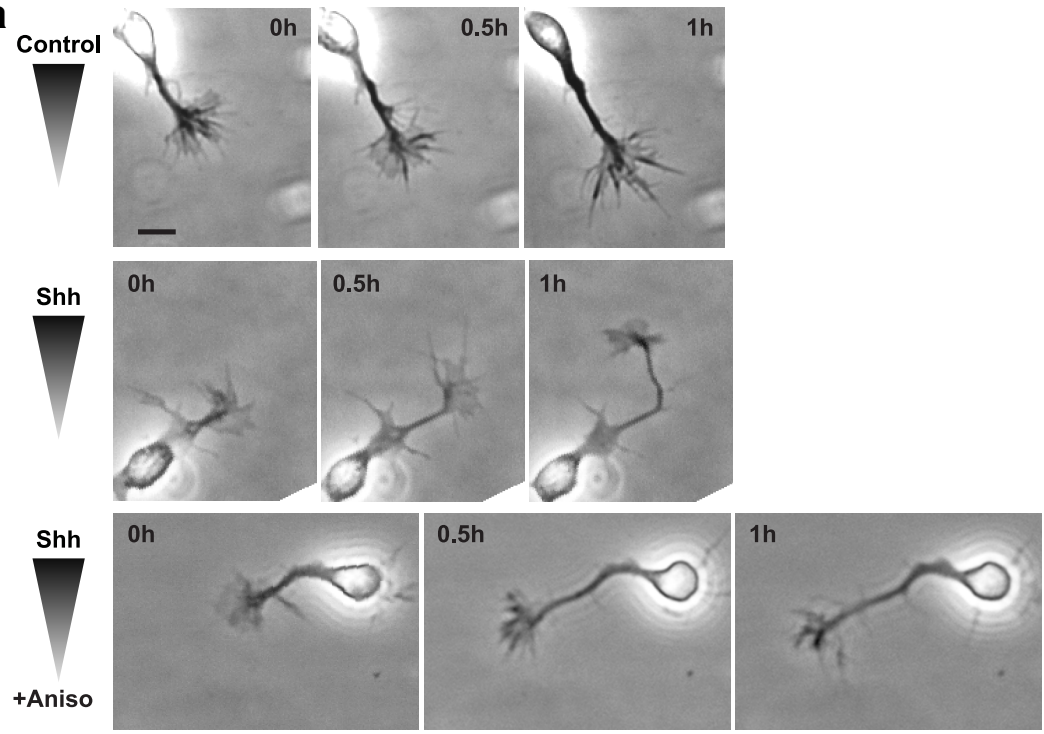

b
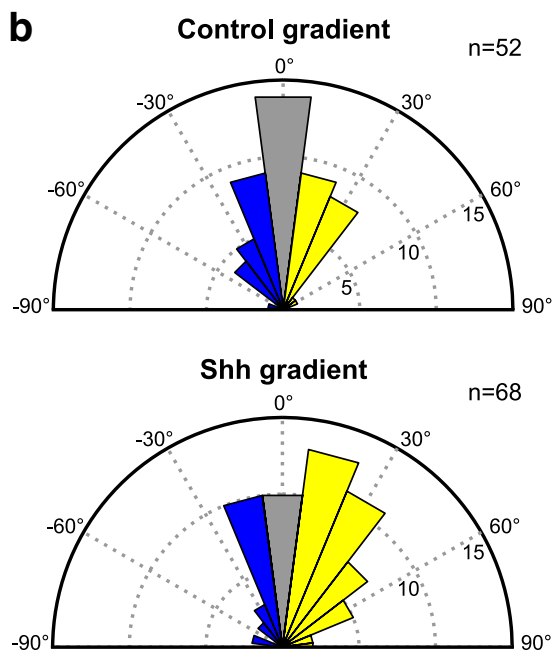

Shh gradient + anisomycin

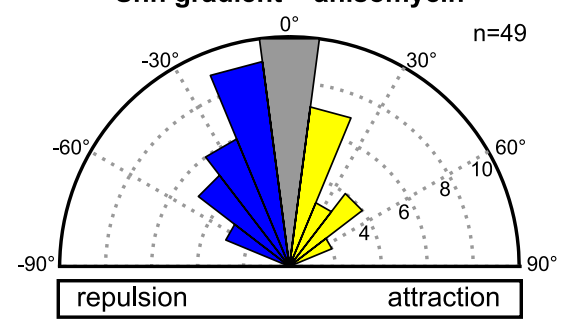

Figure 1. Shh-mediated commissural axon guidance requires translation. $\boldsymbol{a}$, Examples of growing commissural axons imaged in the Dunn chamber. Top, An axon in a control (BSA) gradient does not change its direction of growth. Middle, In an Shh gradient $(0.4 \mu \mathrm{g} / \mathrm{ml}$ in the outer well), an axon turns toward increasing concentrations of Shh. Bottom, A concentration of $100 \mu \mathrm{m}$ anisomycin blocks the ability of axons to turn up a Shh gradient $(0.4 \mu \mathrm{g} / \mathrm{ml}$ in the outer well). Scale bar, $10 \mu \mathrm{m}$. $\boldsymbol{b}$, Commissural neurons were exposed to a control (BSA) gradient, a $0.4 \mu \mathrm{g} / \mathrm{ml} \mathrm{Shh}$ gradient, or a $0.4 \mu \mathrm{g} / \mathrm{ml}$ Shh gradient in the presence of 100 $\mu \mathrm{M}$ anisomycin. The distribution of angles turned by the commissural axons is represented by Rose histograms. Responses of individual neurons were clustered in $15^{\circ}$ bins and the number of neurons per bin is represented by the radius of each segment. Axons in a Shh gradient have a bias toward positive angles turned, indicating attraction. This is abolished by the presence of anisomycin. c, Mean angle turned ( \pm SEM) for commissural axons in a control (BSA) gradient, a Shh gradient, and a Shh gradient with anisomycin. $\boldsymbol{d}$, Axons in a control (BSA) gradient, a Shh gradient, or a Shh gradient with anisomycin have the same net extension. One-way ANOVA; ${ }^{* *} p<0.01$; ns, not significant $(p>0.05)$.

mamatsu ORCA-ER camera. Images were acquired with Volocity (Improvision) and analyzed with ImageJ. For all quantifications, the local background mean value was subtracted. Statistical analyses were performed with GraphPad Prism 5 and 6.
Immunostaining and analysis of commissural neurons in a gradient. Neurons were cultured on $18 \mathrm{~mm}$ square \#3D coverslips and exposed to a Shh gradient in a Dunn chamber, as described above. After specified times, the coverslips were removed from the Dunn chamber and the neurons fixed in 4\% PFA for $20 \mathrm{~min}$ and then immunostained and imaged as described above.

The gradient steepness across the bridge of the Dunn chamber varies and is highest closest to the inner well, where the change in concentration of the guidance cue relative to the ambient concentration is the greatest. We thus analyzed neurons in the inner third of the Dunn chamber bridge, where they were exposed to the steepest gradient. Using ImageJ, the images were oriented such that the Shh or control BSA gradient was always oriented in the same direction. A rectangular ROI was defined for each growth cone such that it could fit inside each half of the growth cone. The mean intensity of the ROI in the growth cone half nearest to and farthest from the highest concentration of Shh was measured. The log of the ratio of near:far fluorescence intensity was calculated; a positive value indicates that the fluorescence intensity was higher in the near half of the growth cone and a negative value indicates that the fluorescence intensity was lower in the near half of the growth cone compared with the far half.

Explant culture and axon severing. The dorsal fifth of E13 rat neural tubes were dissected as described previously (Langlois et al., 2010). The neural tube strips were cut into small explants and then plated on acid-washed and PLL-coated coverslips with five to six explants per well in a 24 -well plate. The medium was changed the next morning for Neurobasal medium supplemented with 2\% B27 and $2 \mathrm{~mm}$ L-glutamine. After 2 DIV, a thin tungsten fiber was used to cut around the explants, severing the axons between the cell bodies and the growth cones. The cut explants were aspirated with a capillary pipette to remove the cell bodies. The isolated growth cones and axons were allowed to recover for $20 \mathrm{~min}$ at $37^{\circ} \mathrm{C}, 5 \% \mathrm{CO}_{2}$ before the addition of drugs for experiments.

FISH. Neurons were stimulated with a gradient of Shh or vehicle in the Dunn chamber for $20 \mathrm{~min}$ and then fixed. A set of 42 labeled oligonucleotide Stellaris probes (Biosearch Technologies) were used to detect rat $\beta$-actin mRNA. These probes were labeled directly with the Quasar 570 dye. Cells were fixed in $4 \%$ paraformaldehyde, rinsed 3 times in PBS/ $\mathrm{MgCl}_{2}$, and placed in $1 \times$ SSC. They were briefly incubated in $10 \%$ formamide/ $1 \times$ SSC and then prehybridized with hybridization buffer alone ( $10 \%$ formamide, $5 \%$ dextran sulfate, $2 \mathrm{mg} / \mathrm{ml}$ bovine serum albumin, $10 \mathrm{~mm}$ ribonucleoside vanadyl complex, $0.05 \times \mathrm{PBS}$, $0.2 \mathrm{mg} / \mathrm{ml}$ salmon sperm DNA, $0.2 \mathrm{mg} / \mathrm{ml}$ tRNA, $1 \times$ SSC) for $1.5 \mathrm{~h}$ at $37^{\circ} \mathrm{C}$. The coverslips were then incubated with the Quasar 570labeled oligonucleotide probe set in hybridization buffer overnight at $37^{\circ} \mathrm{C}$. Cells were rinsed with $10 \%$ formamide/ $1 \times$ SSC 2 times $(20 \mathrm{~min}$ each) at $37^{\circ} \mathrm{C}$, and then rinsed with $1 \times$ SSC alone 5 times ( 5 min each) at 
a
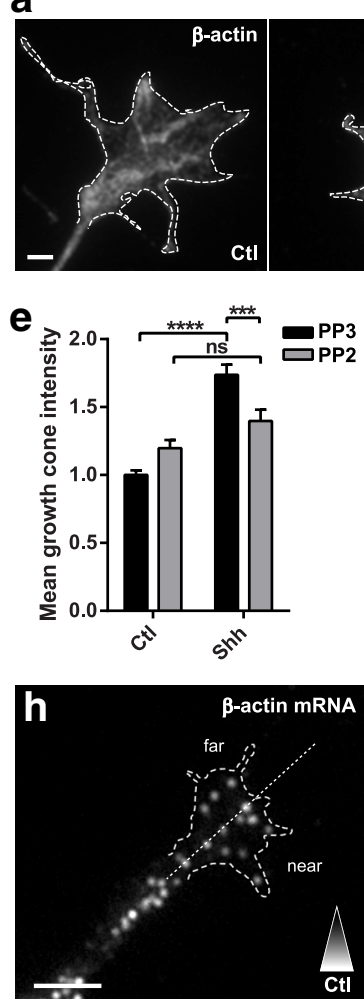

b

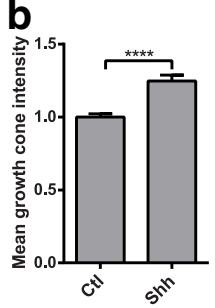

C

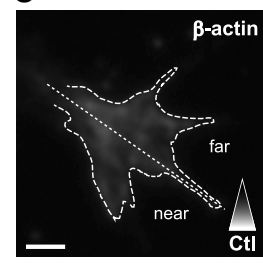

d

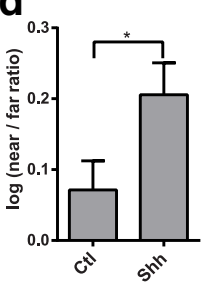

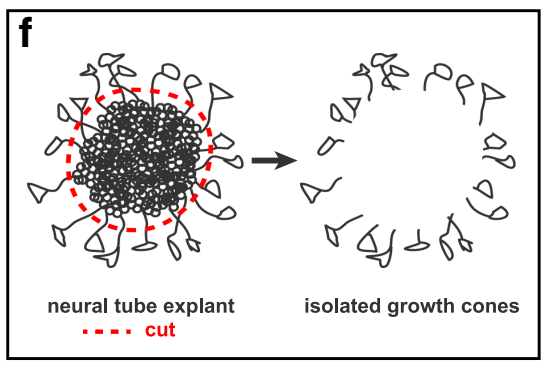

g
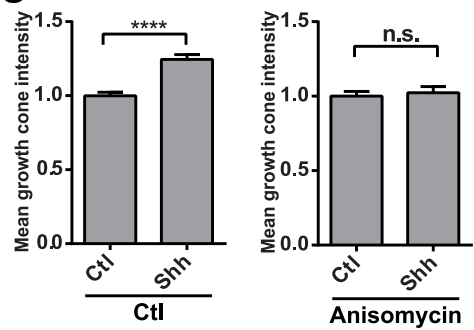

B-actin

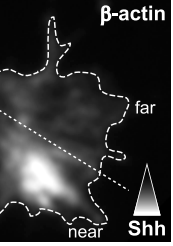

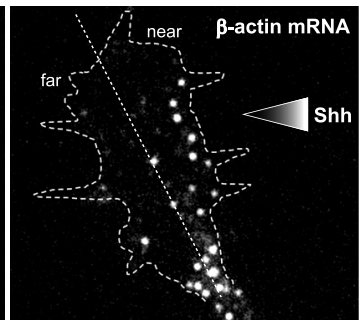

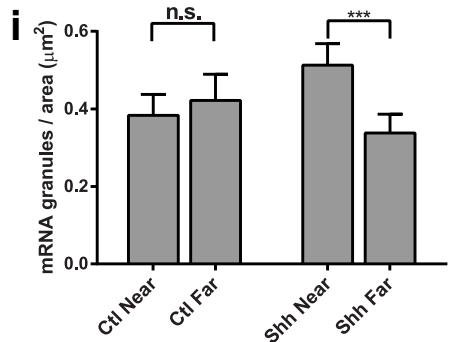

Figure 2. Shh induces local translation of $\beta$-actin in the growth cone. $a, \beta$-actin immunostaining in dissociated commissural neurons. Neurons were stimulated for 30 min with control (BSA; left) or $0.1 \mu \mathrm{g} / \mathrm{ml} \mathrm{Shh}$ (right) before fixation. $\boldsymbol{b}$, Mean relative levels ( \pm SEM) of $\beta$-actin fluorescence in the growth cone of control ( $n=530$ growth cones) and Shh-stimulated ( $n=497 \mathrm{growth}$ cones from four independent experiments) neurons. $c, \beta$-actin immunostaining in growth cones of dissociated commissural neurons in a control (BSA; left) or Shh (right) gradient. Note the polarized distribution of $\beta$-actin to the near side of the growth cone in the Shh gradient. Dashed line separates the near side from the far side of the growth cone with respect to the gradient. $\boldsymbol{d}$, Log (near/far ratio) of $\beta$-actin fluorescence intensity. $n=72$ growth cones (Ctl) and $n=62$ growth cones (Shh) from three independent experiments. Mann-Whitney test. ${ }^{*} p<0.05$. $\boldsymbol{e}$, Dissociated commissural neurons were treated with $0.2 \mu \mathrm{M}$ PP2, a SFK inhibitor, or PP3, an inactive analog of PP2, and then stimulated with $0.1 \mu \mathrm{g} / \mathrm{ml}$ Shh for 30 min before fixation. Neurons were immunostained for $\beta$-actin and mean relative levels ( \pm SEM) of $\beta$-actin fluorescence in the growth cone were measured. $n=268$-351 growth cones for each condition from three independent experiments. One-way ANOVA with Bonferroni's multiple-comparison posttest; ${ }^{* * * *} p<0.0001 ;{ }^{* * *} p<0.001$. Inhibition of SFKs with PP2 blocked the Shh-dependent increase in $\beta$-actin at the growth cone.f, Schematic illustrating the growth cone isolation procedure. After culturing explants for $2 \mathrm{DIV}$, axons were severed along the red dotted line (left). The cell bodies were removed, leaving only isolated axons and growth cones (right). (g) Isolated commissural neuron growth cones were treated with $40 \mu \mathrm{m}$ anisomycin to inhibit translation and then stimulated with $0.1 \mu \mathrm{g} / \mathrm{ml}$ Shh or control (BSA) for $30 \mathrm{~min}$ before fixation. Mean relative levels ( \pm SEM) of $\beta$-actin fluorescence in isolated growth cones of commissural neurons are shown. Shh-stimulation increased $\beta$-actin levels in growth cones (left). This increase was abolished when translation was inhibited with anisomycin (right). $n=222-413$ growth cones per condition from four independent experiments. Student's $t$ test, ${ }^{* * * *} p<$ 0.0001. $\boldsymbol{h}$, FISH showing $\beta$-actin mRNA localization in the growth cone of commissural neurons in a control (BSA) or Shh gradient. The neurons were counterstained with phalloidin to detect the growth cone limits (data not shown, represented by dashed contours). $i$, Number of mRNA granules per square micrometer in the near or far half of the growth cone relative to the gradient for control (BSA; $n=59$ growth cones) or Shh gradients ( $n=73$ growth cones from three independent experiments). The distribution of mRNA granules is biased to the near side of the growth cone only in the Shh gradient. Wilcoxon signed-rank test, ${ }^{* * *} p<0.0005$. Wedges indicate the gradient orientation in $\boldsymbol{c}$ and $\boldsymbol{h}$. Scale bar in $\boldsymbol{a}, \boldsymbol{c}$, and $\boldsymbol{h}, 2 \mu \mathrm{m}$. All fluorescent intensity values were normalized to the mean value in control-stimulated neurons.

room temperature. Labeled oligonucleotide Stellaris probe sets to Dendra-2 and GAPDH were used as controls.

Chick in ovo electroporation. Chick spinal cord electroporation of expression plasmids was performed at Hamburger Hamilton Stage ( $\mathrm{HH}$ st.) $11 / 12$, generally as described previously (Luria et al., 2008). Briefly, a 5-10 mg/ml solution of plasmid DNA (pCherry-ZBP1-WT or pCherryZBP1-Y396F together with Math $\left.1_{\text {promoter }}: G F P\right)$ in TE buffer, pH 7.5 (10 mM Tris-Cl; Fisher Scientific), and 1 mM EDTA (Invitrogen) was injected into the lumbar neural tube through a small eggshell window. The lower bodies of chick embryos were then electroporated using platinum/iridium electrodes (FHC) with the ECM 830 Electro Square Porator (BTX; Harvard Apparatus; Intracel; $30 \mathrm{~V}, 5$ pulses $50 \mathrm{~ms}$ wide at $1 \mathrm{~s}$ interval). The eggshell windows were sealed with Parafilm and incubated at $38^{\circ} \mathrm{C}$ until harvesting at $\mathrm{HH}$ st. 28/29. Spinal cords were dissected and fixed in $4 \%$ PFA and immunostained. The images were analyzed with Image to measure the area of the GFP + commissural tract in the ventral half of the electroporated side of the neural tube relative to the total area of the ventral half of the electroporated side of the neural tube.
Western blotting. After 2 DIV, commissural neurons were lysed in RIPA buffer (50 mM HEPES, pH 7.4, $150 \mathrm{~mm} \mathrm{NaCl}, 10 \%$ glycerol, $1.5 \mathrm{~mm}$ $\mathrm{MgCl}_{2}, 1 \%$ Triton, $1 \%$ SDS, 1 mm EDTA) with PhosSTOP and Protease inhibitor mixture (Roche). Protein lysate samples were separated by SDS-PAGE and transferred to PVDF membrane. Secondary antibodies were conjugated to horseradish peroxidase and visualized with chemiluminescence.

\section{Results}

Translation is required for Shh-mediated axon guidance To test the effect of translation inhibition on commissural axon turning in response to Shh, we assayed the response of commissural axons to Shh gradients in the presence or absence of the translation inhibitor anisomycin using an in vitro assay for axon guidance based on the Dunn chamber (Yam et al., 2009). In this assay, commissural neurons are grown in culture and then exposed to a gradient of Shh in the Dunn chamber. The turning of 

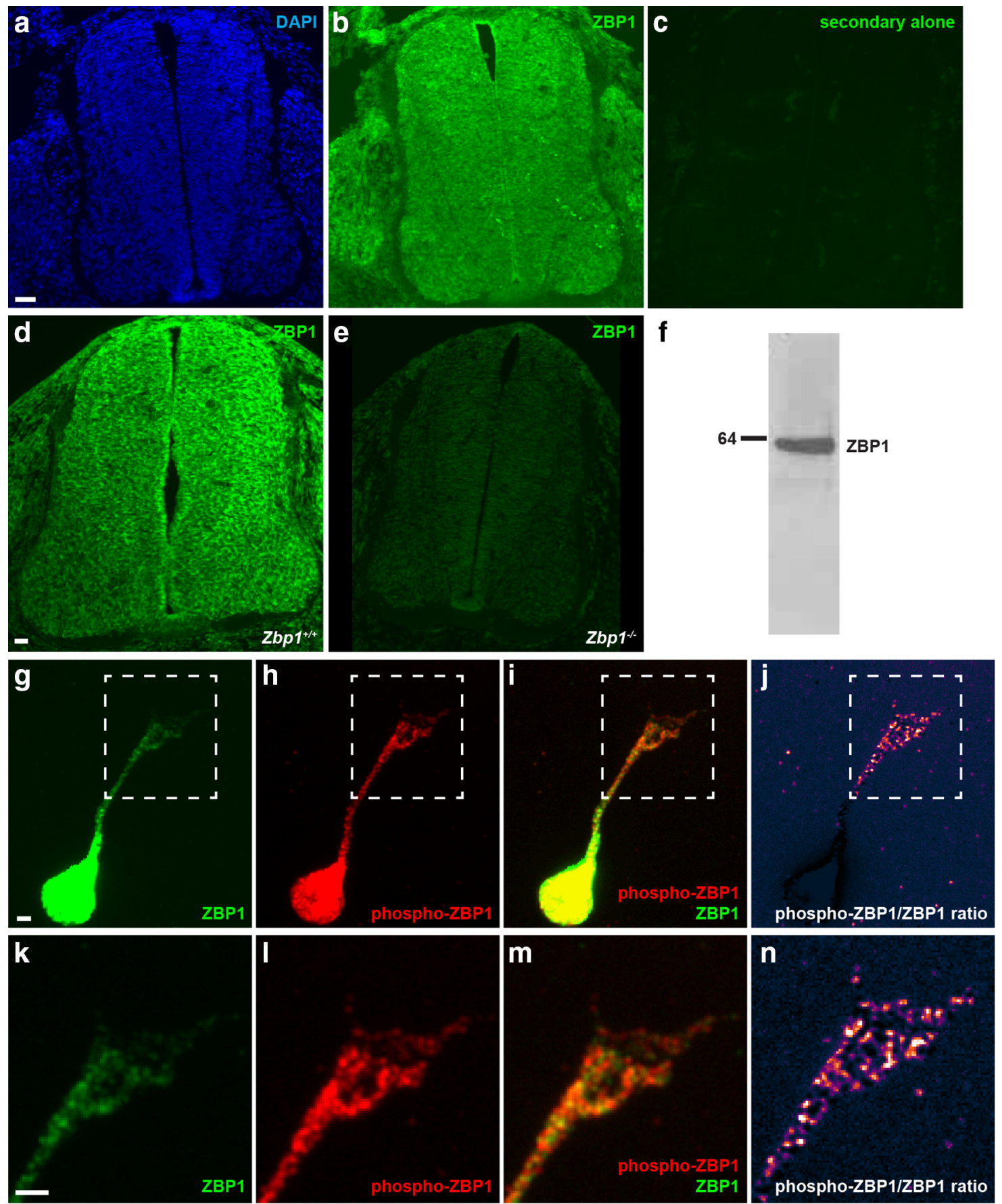

Figure 3. ZBP1 is present and is phosphorylated in commissural neurons. $\boldsymbol{a}-\boldsymbol{c}$, ZBP1 immunostaining of rat spinal cord sections at E13.5: DAPI nuclear counterstain (a), ZBP1 (b), and control secondary antibody alone on an adjacent section (c). Scale bar, $40 \mu \mathrm{m}$. $\boldsymbol{d}, \boldsymbol{e}$, ZBP1 immunostaining on WT (d) and Zbp ${ }^{-1-}$ (e) mouse spinal cord sections at E11.5. Scale bar, $40 \mu \mathrm{m}$. $\boldsymbol{f}$, Western blot of commissural neuron protein extract with the anti-ZBP1 antibody demonstrates that it recognizes only ZBP1. $\boldsymbol{g}-\boldsymbol{n}$, Total ZBP1 and phospho-ZBP1 coimmunostaining on dissociated commissural neurons at 2 DIV. $\boldsymbol{k}-\boldsymbol{n}$ are the zoomed in boxed region of the growth cone from $\boldsymbol{g}-\boldsymbol{j}$, respectively. Total ZBP1 is present in the cell body, axon, and growth cone (green, $\boldsymbol{g}, \boldsymbol{k}$ and $\boldsymbol{i}, \boldsymbol{m}$ ). Phospho-ZBP1 is also present in the cell body, axon, and growth cone (red, $\boldsymbol{h}, \boldsymbol{l}$ and $\mathbf{i}, \boldsymbol{m}) . \boldsymbol{j}, \boldsymbol{n}$, Pseudocolor heatap of the phospho-ZBP1/total ZBP1 intensity ratio. Phospho-ZBP1 is enriched relative to total ZBP1 in the distal part of the axon and the growth cone compared with the cell body. Scale bar, $2 \mu \mathrm{m}$.

axons is then imaged and measured in response to the Shh gradient. In a control (BSA) gradient, axons grow with no change in their trajectory (Fig. 1a, top). In the presence of a Shh gradient, the axons reorient such that there is a bias for the axons to turn up the gradient (Fig. 1 $a$, middle). When translation is inhibited with anisomycin, a Shh gradient fails to induce this reorientation of the axons up the gradient. Instead, the axons continue growing along their original direction (Fig. $1 a$, bottom). The angle turned by the axon is defined as the angle between the initial orientation of the axon and the final orientation of the distal segment of the axon (positive for turns up the gradient; negative for turns down the gradient; Yam et al., 2009). Quantification of the angle turned demonstrated that there was no net turning of axons in a control gradient, with an angle turned of $-1.2 \pm 3.6^{\circ}$ (Fig. $\left.1 b, c\right)$. In the presence of a Shh gradient, there was significant turning of the axons toward the gradient of $16 \pm 4.2^{\circ}$. When translation was inhibited by anisomycin, axons did not turn toward the Shh gradient and the mean angle turned of $-3.5 \pm 4.4^{\circ}$ was not signifi- 
cantly different from the control (Fig. $1 b, c)$. We found no difference in axon extension under all conditions (Fig. 1d), demonstrating that the lack of turning toward the Shh gradient in the presence of anisomycin was not due to a reduction in axon growth. Therefore, Shh-mediated axon guidance requires translation.

Shh induces the local translation of $\boldsymbol{\beta}$-actin in growth cones

The turning of growth cones from Xenopus retinal and spinal neurons and rodent cortical neurons toward guidance cues such as Netrin-1 and BDNF depends on the local translation of $\beta$-actin at the growth cone (Leung et al., 2006; Yao et al., 2006; Sasaki et al., 2010; Welshhans and Bassell, 2011). In particular, BDNF or Netrin-1 stimulation increases $\beta$-actin protein in the growth cone (Leung et al., 2006; Yao et al., 2006; Sasaki et al., 2010; Welshhans and Bassell, 2011). Therefore, we hypothesized that Shh might also elicit changes in $\beta$-actin in the growth cone of commissural neurons. We stimulated commissural neurons with Shh and fixed and immunostained for $\beta$-actin protein. Therefore, we detect both polymerized and nonpolymerized actin (F- and G-actin, respectively). $\beta$-actin protein was present throughout the growth cone, with some local variations or patches, as has been observed previously (Spooner and Holladay, 1981; Welshhans and Bassell, 2011). We found that Shh stimulation increased $\beta$-actin protein in the growth cone (Fig. 2a,b). When commissural neurons were exposed to a Shh gradient in a Dunn chamber, the increase in $\beta$-actin was localized to the side of the growth cone exposed to the higher Shh concentration (Fig. 2c). Measurement of the ratio of $\beta$-actin in the near compared with the far side of the growth cone, relative to the gradient, showed that growth cones in a Shh gradient have significantly more $\beta$-actin on the near versus the far side of the growth cone compared with growth cones in a control gradient (Fig. $2 d$ ). Therefore, a Shh gradient can polarize $\beta$-actin in the growth cone, with more $\beta$-actin being present on the side of the growth cone closer to the source of Shh. This suggests that Shh may regulate $\beta$-actin levels in axon guidance.

Shh guides commissural axons through activation of SFKs (Yam et al., 2009). To determine whether the change in $\beta$-actin protein at the growth cone was downstream of SFK activation, we blocked SFK activity. The SFK inhibitor PP2 effectively blocked the Shh-dependent increase in $\beta$-actin at the growth cone, whereas its inactive analog PP3 had no effect (Fig. 2e). This demonstrates that the Shh-dependent increase in $\beta$-actin requires SFK activity.

We next tested whether the Shh-induced increase in $\beta$-actin protein was dependent on local translation of $\beta$-actin at the growth cone. Explants of dorsal neural tube tissue were grown in culture. After 2 DIV, growth cones and axons had migrated out of the explant and could be severed from the cell bodies. The cell bodies were subsequently removed by aspiration, leaving only the axons and growth cones (Fig. $2 f$ ). Exposure of the isolated growth cones to Shh increased $\beta$-actin in the growth cone by 1.2 -fold (Fig. $2 g$ ), similar to what was observed for growth cones of intact neurons (Fig. 2b). This indicates that the increase in growth cone $\beta$-actin in response to Shh does not depend on protein transport from the cell body, but rather occurs locally in the growth cone. When translation in the isolated growth cone preparation was inhibited by anisomycin, Shh failed to induce a change in $\beta$-actin at the growth cone (Fig. $2 g$ ). Together, this demonstrates that the Shh-induced increase in $\beta$-actin at the growth cone depends on local translation.

In addition to increasing $\beta$-actin protein in the growth cone, neurotrophin stimulation also increases $\beta$-actin mRNA in the growth cone (Zhang et al., 1999, 2001). Indeed, local BDNF application from a point source can induce the asymmetric distribution of $\beta$-actin mRNA in growth cones (Yao et al., 2006). We applied a Shh gradient to dissociated commissural neurons in the Dunn chamber, fixed the neurons, and detected $\beta$-actin mRNA with FISH. Growth cones in a control gradient had no significant difference in the number of $\beta$-actin mRNA granules on the near and far side of the growth cone $(0.38 \pm 0.05$ and $0.42 \pm 0.07$ granules $/ \mu \mathrm{m}^{2}$, respectively) relative to the gradient. In contrast, when a Shh gradient was applied, the number of $\beta$-actin mRNA granules increased on the near side of the gradient to $0.51 \pm 0.06$ granules $/ \mu \mathrm{m}^{2}$ compared with $0.34 \pm 0.05$ granules $/ \mu \mathrm{m}^{2}$ on the far side of the gradient (Fig. $2 h, i$ ). Therefore, Shh regulates not only local $\beta$-actin protein synthesis in the growth cone, but also $\beta$-actin mRNA localization.

\section{Shh induces Zbp1 phosphorylation in commissural neuron growth cones}

One regulator of $\beta$-actin mRNA translation is ZBP1. Therefore, we hypothesized that these Shh-induced changes in $\beta$-actin translation were dependent on ZBP1. We first examined the expression of ZBP1 by immunostaining rat E13.5 spinal cord sections (the stage at which we dissect commissural neurons and the stage at which commissural axons are being guided toward the 
floorplate by Shh; Fig. 3b), and mouse E11.5 spinal cord sections (the equivalent mouse developmental stage; Fig. $3 d$ ). ZBP1 is expressed throughout the neural tube (Fig. $3 b, d$ ). No fluorescence was detected when the primary antibody was omitted (Fig. $3 c$ ) and antibody specificity was verified by immunostaining $Z b p 1^{-1-}$ spinal cord sections with the anti-ZBP1 antibody, which showed minimal reactivity with the $Z b p 1^{-1-}$ tissue (Fig. $3 e$ ). Furthermore, Western blotting of commissural neuron extracts with the anti-ZBP1 antibody detected only one band at $\sim 64 \mathrm{kDa}$ (Fig. 3f).

Immunostaining of dissociated commissural neurons revealed that both total ZBP1 and phospho-ZBP1, which was detected with an antibody specific to the Tyr396 site (Sasaki et al., 2010), were expressed throughout the neuron (Fig. 3g-j), including the growth cone (Fig. $3 g-n$ ). When the ratio of phosphoZBP1 relative to total ZBP1 was calculated (Fig. $3 j, n$ ), it showed that phospho-ZBP1 was enriched in the growth cone relative to total ZBP1.

To test whether Shh regulates ZBP1 in commissural neuron growth cones, we stimulated commissural neurons with Shh, fixed the cells, and immunostained for total ZBP1 and phosphoZBP1 (Fig. 4a). We quantified the total ZBP1 and phospho-ZBP1 fluorescence in the growth cone and found that both total ZBP1 and phospho-ZBP1 levels increased in the growth cone after Shh stimulation, by 1.7-fold and 2.4-fold, respectively (Fig. 4b). Notably, the increase in phospho-ZBP1 level was significantly greater than the increase in total ZBP1, such that Shh stimulation also increased the ratio of phospho-ZBP to total ZBP1 in the growth cone by 1.3 -fold (Fig. $4 b$, right). Phosphorylation of ZBP1 at Tyr396 is critical for the release of $\beta$-actin mRNA from ZBP1 (Hüttelmaier et al., 2005), which then allows the mRNA to be translated (Wu et al., 2015). Therefore, the Shh-dependent increase in both the absolute and relative level of phospho-ZBP1 in the growth cone supports a model in which Shh signaling leads to phosphorylation of ZBP1 in the growth cone, which promotes local translation of its cargo mRNAs.

\section{ZBP1 phosphorylation is required for Shh-mediated axon guidance}

To test whether ZBP1 is required for Shh-mediated axon guidance, we perturbed ZBP1 activity in dissociated commissural neurons and then tested their ability to respond to a Shh gradient in the Dunn chamber. To perturb ZBP1 activity in commissural neurons, we expressed ZBP1 Y396F, a mutant that cannot be phosphorylated. ZBP1 Y396F can still bind to and transport $\beta$-actin mRNA, but cannot release its mRNA cargo for translation, and thus acts as a dominant-negative mutant for translation (Hüttelmaier et al., 2005; Sasaki et al., 2010). Commissural neurons expressing either GFP or ZBP1 WT were able to turn up a gradient of Shh (Fig. $5 a, b$ ), with a mean angle turned of $14.1 \pm$ $4.2^{\circ}$ and $15.4 \pm 4.5^{\circ}$, respectively, similar to untransfected neurons (Fig. 1). However, when ZBP1 activity was perturbed by expression of ZBP1 Y396F, commissural neurons failed to respond to a Shh gradient, with no net turning $\left(2.1 \pm 4.2^{\circ}\right.$; Fig. $5 a, b)$. Axon growth was not significantly different with expression of the different proteins (Fig. $5 c$ ), eliminating the possibility that the inability of ZBP1 Y396F-expressing neurons to respond to a Shh gradient was due to a lack of axon growth. Therefore, correct regulation of local translation through phosphorylation of ZBP1 is required for commissural neurons to be guided by Shh gradients in vitro.
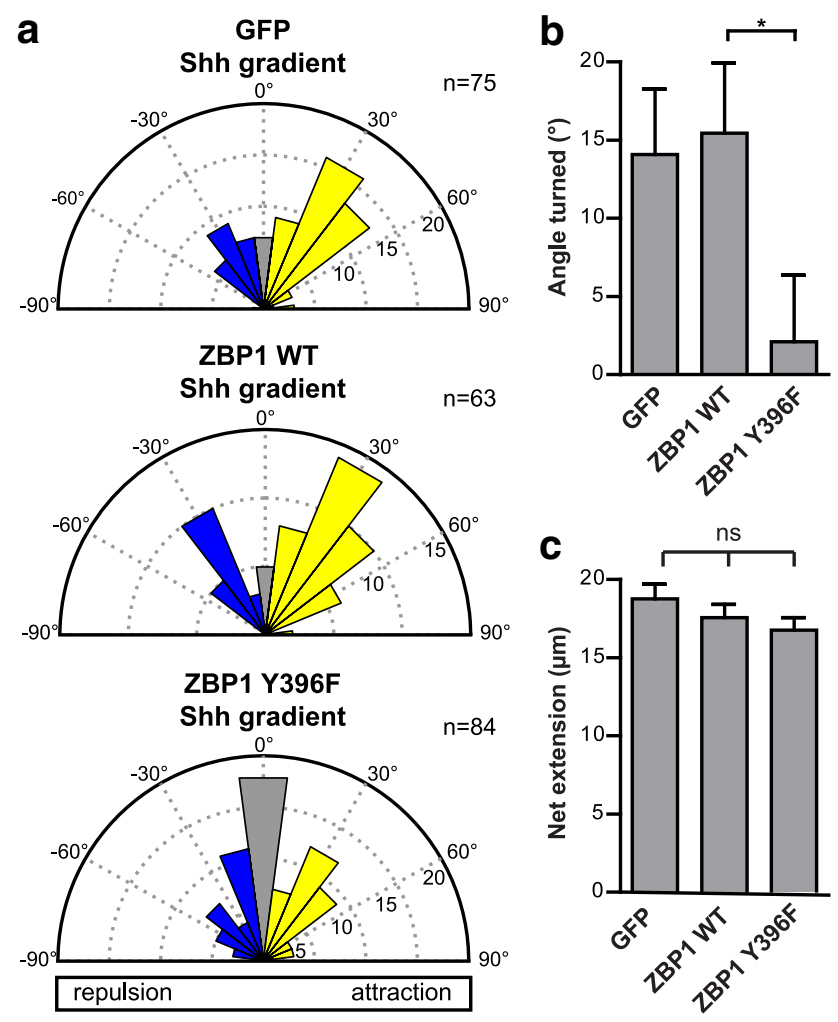

Figure 5. ZBP1 phosphorylation is required for Shh-mediated growth cone turning. $\boldsymbol{a}$, Commissural neurons expressing GFP (control), ZBP1 WT, or ZBP1 Y396F, which cannot be phosphorylated, were exposed to a $0.1 \mu \mathrm{g} / \mathrm{ml}$ Sh gradient in the Dunn chamber. The distribution of angles turned is represented by Rose histograms. Responses of individual neurons were clustered in $15^{\circ}$ bins and the number of neurons per bin is represented by the radius of each segment. The positive angles turned indicate attraction by the Shh gradient for the GFP- and ZBP1 WT-expressing neurons. However, expression of ZBP1 Y396F inhibits the turning of axons up a Shh gradient, with the angles turned clustering around zero. $\boldsymbol{b}$, Angle turned (mean \pm SEM) for commissural neurons expressing GFP (control; $n=75)$, ZBP1 WT ( $n=63$ ), or ZBP1 Y396F ( $n=84$ from four independent experiments). Student's $t$ test, ${ }^{*} p<0.05$. c, There was no significant difference in the net axon growth (mean $\pm \mathrm{SEM}$ ) of commissural neurons expressing GFP (control; $n=75)$, ZBP1 WT ( $n=63)$, or ZBP1 Y396F $(n=84)$ in a $0.1 \mu \mathrm{g} / \mathrm{ml} \mathrm{Shh}$ gradient. One-way ANOVA, $p=0.26$.

\section{ZBP1 activity is required for correct commissural axon guidance in vivo}

Our in vitro results imply that ZBP1 is necessary for Shhmediated commissural axon guidance. To determine whether this translates to a requirement for ZBP1 for commissural axon guidance in vivo, we examined the spinal cord of $Z b p 1^{-1-}$ mice. Spinal cord sections of WT and $Z b p 1^{-1-}$ mice were immunostained for Tag1, a marker of commissural neurons. We found that, compared with WT mice, the commissural axons of $Z b p 1^{-1-}$ mice were more dispersed and invaded the ventral spinal cord and motor column (Fig. $6 a, b$ ). We quantified the ratio of the area occupied by commissural axons to the total area of the ventral spinal cord (Charron et al., 2003) and found a significant increase in the area occupied by Tag1 + axons in the ventral spinal cord of $Z b p 1^{-1-}$ mice compared with WT mice (Fig. $6 b$ ). Therefore, commissural axons of $Z b p 1^{-1-}$ mice have guidance defects.

In $Z b p 1^{-1-}$ mice, ZBP1 is absent from the entire embryo, so both the transport and the regulated translation of $\beta$-actin mRNA by ZBP1 is disrupted. To determine whether translational regulation by $\mathrm{ZBP} 1$ phosphorylation is important for axon guidance, we tested whether expression of the ZBP1 Y396F mutant, 
which can transport mRNA but not release it and thus is a dominant-negative mutant for translation (Hüttelmaier et al., 2005), could perturb commissural axon guidance. We electroporated plasmids encoding either ZBP1 WT or ZBP1 Y396F, together with Math $1_{\text {promoter }}:$ GFP to mark Math1+ commissural neurons, into the neural tube of the developing chick embryo. The embryos were allowed to develop in ovo, fixed, and the commissural axon tracts analyzed by GFP fluorescence in the spinal cord. In neurons expressing ZBP1 WT, the axons had a well organized trajectory from the dorsal to the ventral spinal cord. In contrast, in neurons expressing ZBP1 Y396F, the axon tract was wider and the axons were more dispersed, invading the ventral spinal cord and motor column (Fig. 6c). This was also demonstrated by the significantly larger area occupied by the GFP + axons in the ZBP1 Y396F electroporated embryos compared with the ZBP1 WT embryos (Fig. 6d).

In summary, both genetic ablation of ZBP1 and inactivation of ZBP1 using ZBP1 Y396F gave a similar phenotype (Fig. 6e), indicating that ZBP1 activity in commissural neurons is necessary for correct commissural axon guidance in vivo. Strikingly, the phenotype we observed when $\mathrm{ZBP} 1$ was disrupted is similar to the phenotype we observed in $\mathrm{Boc}^{-1-}$ mice (Okada et al., 2006) and mice with conditional ablation of Smo (Charron et al., 2003), two mutations that affect Shhmediated axon guidance. Together with our in vitro data showing that translational regulation by ZBP1 is required for commissural axons to turn toward a Shh gradient, we demonstrate that ZBP1 is required for Shh-mediated axon guidance in vitro and in vivo.

\section{Discussion}

In this study, we demonstrate that Shhmediated axon guidance requires translation. In particular, we find that $\beta$-actin protein is locally synthesized at the growth cone in response to Shh. This increase in $\beta$-actin protein requires SFK activity. We show that ZBP1, which is phosphorylated by SFKs (Hüttelmaier et al., 2005; Sasaki et al., 2010), is phosphorylated in response to Shh stimulation and propose that it is responsible for regulating the local SFK-dependent synthesis of $\beta$-actin in the growth cone in response to Shh. ZBP1 activity is critical for growth cone turning because we found that ZBP1 and phosphorylation of ZBP1 are required for Shhmediated axon guidance in vitro and in vivo.
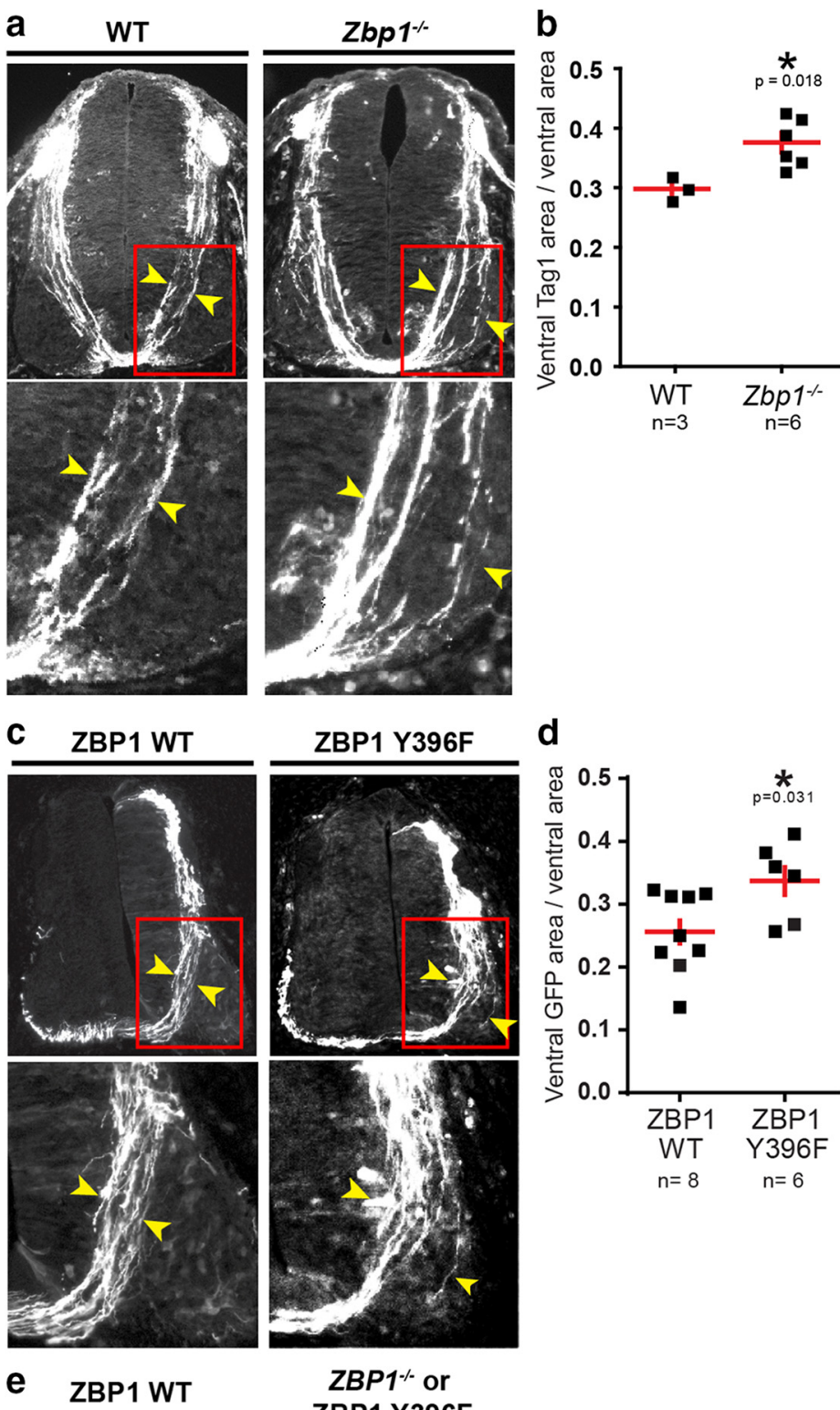

ZBP1\% or ZBP1 Y396F
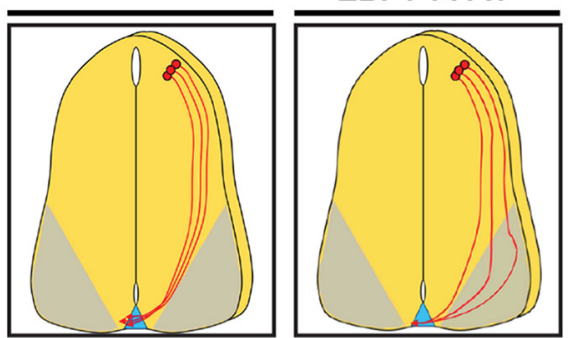

Figure 6. Disruption of ZBP1 function in vivo perturbs commissural axon guidance. $a$, WT and $Z b p 1^{-/-}$mice spinal cord cross-sections immunostained for Tag1, a marker of precrossing commissural axons. The regions boxed in red on the top panels are enlarged on the bottom panels. The commissural axon tract in $\mathrm{Zbp1}^{-1}$ mice is wider compared with WT mice and invades the motor column. Yellow arrowheads mark the width of the axon tract. $\boldsymbol{b}$, Ventral Tag1+ area relative to the total ventral area is greater in Zbp1 ${ }^{-1-}$ mice compared with WT mice. Student's $t$ test, $p=0.018$. c, Chick neural tubes were electroporated with

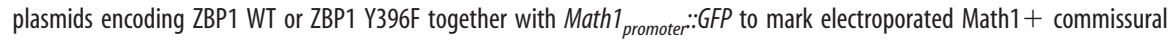
neurons. The images of the chick spinal cord cross-sections represent the GFP + neurons. The regions boxed in red on the top panels are enlarged on the bottom panels. The commissural axon tract in ZBP1 Y396F-electroporated animals is wider compared with ZBP1 WT-electroporated animals and invades the motor column. Yellow arrowheads mark the width of the axon tract. $\boldsymbol{d}$, Mean ( \pm SEM) ratio of the ventral GFP + area to the total ventral area. The ventral GFP + area relative to the total ventral area is higher in ZBP1 Y396F-electroporated animals compared with ZBP1 WT-electroporated animals. $n=$ number of embryos analyzed, with at least four sections per embryo. $e$, Schematic of the commissural axon tract in wild-type and ZBP1-disrupted (Zbp ${ }^{-1-}$ mice or ZBP1 Y396F-expressing commissural neurons) conditions. 


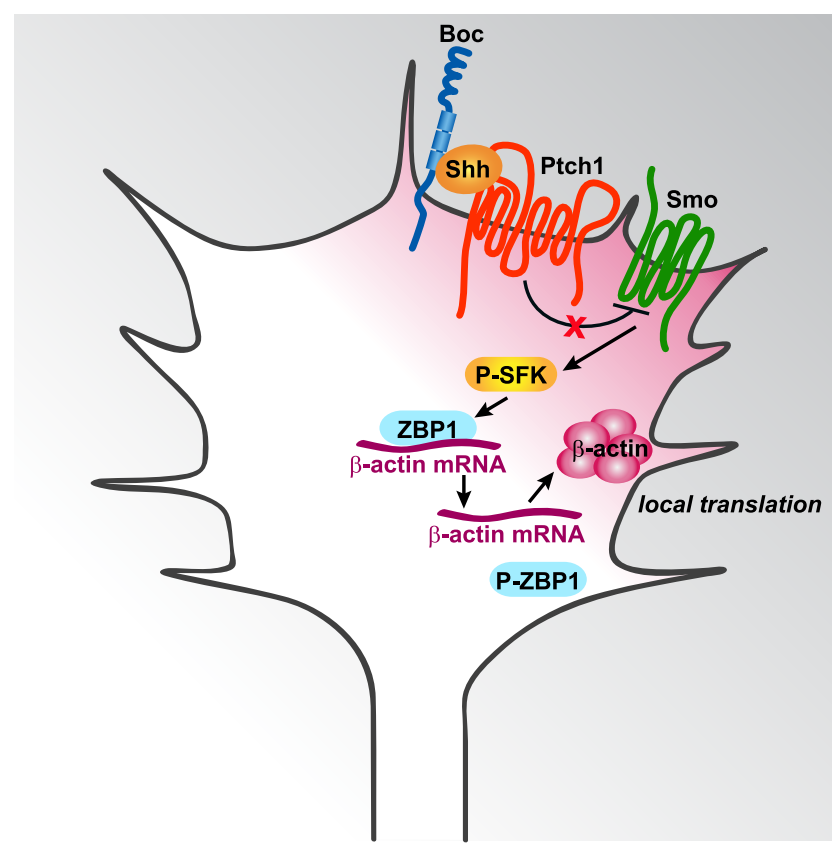

Figure 7. Shh guides commissural axons through ZBP1-mediated local translation. In commissural axon attraction, Shh binds to Boc and presumably Ptch1, leading to Smo and SFK activation. SFKs phosphorylate ZBP1, enabling it to release $\beta$-actin mRNA in the growth cone. The $\beta$-actin mRNA is then locally translated in the growth cone to produce $\beta$-actin protein, which facilitates polarized actin polymerization required for growth cone turning up Shh gradients.

Exposure of growth cones to a Shh gradient induces polarized activation of SFKs (Yam et al., 2009) and polarized localization of $\beta$-actin (Fig. 2). This Shh-dependent increase in $\beta$-actin requires SFK activity (Fig. 2). Therefore, we propose (Fig. 7) that, in axon guidance, Shh binds to its receptor Boc (Okada et al., 2006) and possibly to Ptch1. This then activates Smo (Charron et al., 2003; Yam et al., 2009), which leads to activation of SFKs (Yam et al., 2009). Polarized activation of SFKs by a Shh gradient leads to polarized phosphorylation of ZBP1. In turn, phosphorylation of ZBP1 by SFKs acts as a switch to release $\beta$-actin mRNA from ZBP1, allowing $\beta$-actin mRNA to be translated (Hüttelmaier et al., 2005). Increased phosphorylation of ZBP1 on the side of the growth cone exposed to higher Shh concentrations leads to polarized release of $\beta$-actin mRNA and to increased local translation of $\beta$-actin. The newly synthesized pool of $\beta$-actin is then used to promote polarized actin polymerization, which propels growth cone turning up a Shh gradient.

There have been some elegant studies demonstrating that mRNAs can be translated locally in axons in vivo. For example, based on fluorescent translation reporter analysis, it has been demonstrated that the $3^{\prime}$-UTR of EphA2 mRNA is sufficient to direct synthesis of a reporter in distal segments of commissural axons after they cross the floorplate (Brittis et al., 2002). This suggests that local translation of EphA2 occurs in the distal part of the axon during and after midline crossing. However, a role for this process in axon guidance has not yet been demonstrated. Retinal axon guidance requires NF-protocadherin. Retinal growth cones expressing a NF-protocadherin translation reporter based on its $3^{\prime}$-UTR show translation reporter activity in isolated growth cones (without cell bodies) in vitro and at the caudal turn within the mid-optic tract in vivo. This suggests that local translation of NF-protocadherin is required for retinal axon guidance in vivo (Leung et al., 2013). Recently, ribosome-bound
mRNAs have been isolated from retinal ganglion cell axons at various developmental stages and analyzed by deep sequencing. Shigeoka et al. (2016) demonstrated that the axonal translatome evolves over time and also identified sequence elements generated by alternative splicing that may promote axonal mRNA translation.

$Z b p 1^{-1-}$ mice have high perinatal mortality, with only $50 \%$ remaining alive by P3 (Hansen et al., 2004), and no detailed study of the nervous system of $Z b p 1^{-1-}$ mice has yet been published. Heterozygous mice are viable and peripheral sensory neurons isolated from $Z b p 1^{+/-}$mice have reduced axon branching and growth in culture. These mice also have a reduced ability to deliver $\beta$-actin mRNA and other mRNAs into mature axons after injury and exhibit decreased axonal regeneration in vivo after sciatic nerve crush (Donnelly et al., 2011). Therefore, ZBP1 appears to have a role in the transport and translation of mRNA cargos that are important for axonal regeneration in vivo. In Xenopus, loss of function of the ZBP1 ortholog Vg1RBP in retinal ganglion cells causes severe defects in RGC axon terminal arborization. Although Vg1RBP disruption reduced the branching and complexity of axon terminals, long-range guidance from the retina to the tectum remained unaffected (Kalous et al., 2014) despite attractive turning to a Netrin-1 gradient being abolished in Vg1RBP-perturbed axons in vitro (Leung et al., 2006; Kalous et al., 2014).

In contrast, we found that the commissural axons of $\mathrm{Zbp}^{-1-}$ mice are misguided and invade the ventral spinal cord and motor column. This phenocopies the commissural axon guidance defects seen in $\mathrm{Boc}^{-1-}$ (Okada et al., 2006) and Smo conditional knock-out mice (Charron et al., 2003), which have genetically ablated components of the Shh signaling pathway involved in axon guidance. Although we cannot eliminate the possibility that $\mathrm{ZBP} 1$ is also involved in axon fasciculation, our in vitro data clearly demonstrate that Shh-induced turning of commissural axons requires ZBP1 activity. Therefore, the most parsimonious explanation for the deviations in axon trajectories that we observe in $Z b p 1^{-1-}$ mice is that these mice have a defect in Shh-mediated commissural axon guidance. Numerous studies have demonstrated that inhibiting local translation in vitro abolishes the turning response to certain guidance cues (Jung et al., 2012). Notably, this is the first identification of an in vivo axon guidance phenotype in $\mathrm{Zbp1}^{-/-}$mice and complements the emerging evidence (Leung et al., 2013) that local translation is important for axon guidance in vivo.

We found that expression of ZBP1 Y396F does not affect the rate of axon extension (Fig. 5), consistent with previous findings that there is no difference in outgrowth rate of axons of cortical neurons from $Z b p 1^{-1-}$ mice compared with $Z b p 1^{+/+}$mice (Welshhans and Bassell, 2011). Moreover, basal levels of $\beta$-actin mRNA and protein in the growth cone is not influenced by ZBP1 (Zhang et al., 2001; Sasaki et al., 2010; Welshhans and Bassell, 2011). Therefore, ZBP1 appears to regulate $\beta$-actin mRNA in response to an external cue, but not basal levels of $\beta$-actin mRNA and protein.

ZBP1 is also required for growth cone turning of cortical neurons toward Netrin-1 in vitro (Welshhans and Bassell, 2011). In vivo, Netrin-1 (together with Shh and VEGF) attracts commissural axons ventrally to the floorplate (Kennedy et al., 1994; Serafini et al., 1994; Ruiz de Almodovar et al., 2011; Sloan et al., 2015). However, the commissural axon phenotype that we observe in $Z b p 1^{-1-}$ mice phenocopies mutations in the Shh signaling pathway (Charron et al., 2003; Okada et al., 2006) but not mutations in the Netrin-1 signaling pathway (Serafini et al., 1996; 
Fazeli et al., 1997). This may be because Netrin-1, in addition to inducing growth cone turning, also promotes commissural axon outgrowth, whereas Shh induces only growth cone turning, not commissural axon outgrowth (Charron et al., 2003; Yam et al., 2009).

In addition, the in vivo dependence of axon guidance responses on local translation may vary according to the local microenvironment. For example, the dependence of Sema3Ainduced growth cone collapse on protein synthesis varies according to the concentration of guidance cue (Li et al., 2004; Manns et al., 2012; Nédelec et al., 2012). At low concentrations ( $\leq 600$ $\mathrm{ng} / \mathrm{ml}$ ) of Sema3A, Sema3A-induced growth cone collapse is protein synthesis dependent, whereas, at high concentrations of Sema3A, growth cone collapse is protein synthesis independent (Li et al., 2004; Roche et al., 2009; Manns et al., 2012; Nédelec et al., 2012). Even at low concentrations of Sema3A, not all of the growth cone collapse response is dependent on protein synthesis (Manns et al., 2012; Nédelec et al., 2012). Moreover, the relative dependence on protein synthesis of Sema3A-induced growth cone collapse of DRG neurons is influenced by the concentration of NGF in the culture medium (Manns et al., 2012). Therefore, it is plausible that, in vivo, signals in the microenvironment can modulate the protein-synthesis dependence of a particular guidance cue response. Therefore, although $\mathrm{ZBP} 1$ is required for Netrin-1-mediated axon guidance of cortical neurons in vitro, this may not translate to the action of Netrin-1 on commissural neurons in vivo. For example, if Netrin-1 is of sufficiently high concentration in the spinal cord, it may guide commissural neurons in a protein-synthesis-independent manner.

Recently, knock-down of IMP2, an RNA-binding protein related to ZBP1, has also resulted in commissural axon guidance defects (Preitner et al., 2016). IMP2 knock-down had no effect on the trajectory of precrossing commissural neurons to the floorplate, consistent with its low expression in precrossing commissural neurons. Instead, IMP2 knock-down led to stalling of commissural axons at the floorplate, consistent with its strong expression in crossing and postcrossing commissural neurons. In contrast to the regulation of ZBP1 activity by Shh, it is unknown whether IMP2 is regulated downstream of a guidance cue. The floorplate-crossing phenotype is likely due to decreased expression of Robo1, an IMP2 target, in axons when IMP2 is reduced. Whether this is due to IMP2 regulating local translation of Robo1 has yet to be determined.

ZBP1 itself has other mRNA targets in addition to $\beta$-actin. In particular, mRNA targets of proteins involved in cell motility, cell adhesion, or the actin cytoskeleton could also contribute to regulating the changes in the cytoskeleton and adhesion that underlie growth cone-turning responses. For example, in nonneuronal cells, ZBP1 can localize mRNA encoding a subunit of the Arp2/3 complex, an important regulator of the actin cytoskeleton (Gu et al., 2012). In human pluripotent stem cells, ZBP1 binds mRNAs of multiple genes of the integrin family and regulates their levels, affecting cell adhesion (Conway et al., 2016). Further work is needed to identify and characterize other ZBP1 target mRNAs that, in addition to $\beta$-actin, mediate Shh-directed axon guidance.

Our identification of ZBP1 as a downstream mediator of Shh in commissural axon guidance provides the first link between noncanonical Shh signaling and growth cone cytoskeleton remodelling. We show that Shh stimulation increases ZBP1 phosphorylation in the growth cone, suggesting that the phosphorylation of ZBP1 locally in the growth cone and subsequent local translation of its mRNA cargo allows the growth cone to respond to Shh gradients in a spatially defined manner. Indeed, a
ZBP1 mutant, which cannot be phosphorylated and therefore cannot release its cargo for local translation, blocks the ability of commissural axons to be guided by Shh. Consistent with this, we also show that $Z b p 1^{-1-}$ mice have a commissural axon guidance defect, implicating ZBP1 as a key player in noncanonical Shh signaling.

\section{References}

Brittis PA, Lu Q, Flanagan JG (2002) Axonal protein synthesis provides a mechanism for localized regulation at an intermediate target. Cell 110: 223-235. CrossRef Medline

Campbell DS, Holt CE (2001) Chemotropic responses of retinal growth cones mediated by rapid local protein synthesis and degradation. Neuron 32:1013-1026. CrossRef Medline

Charron F, Stein E, Jeong J, McMahon AP, Tessier-Lavigne M (2003) The morphogen Sonic hedgehog is an axonal chemoattractant that collaborates with Netrin-1 in midline axon guidance. Cell 113:11-23. CrossRef Medline

Conway AE, Van Nostrand EL, Pratt GA, Aigner S, Wilbert ML, Sundararaman B, Freese P, Lambert NJ, Sathe S, Liang TY, Essex A, Landais S, Burge CB, Jones DL, Yeo GW (2016) Enhanced CLIP uncovers IMP proteinRNA targets in human pluripotent stem cells important for cell adhesion and survival. Cell Rep 15:666-679. CrossRef Medline

Dessaud E, McMahon AP, Briscoe J (2008) Pattern formation in the vertebrate neural tube: a sonic hedgehog morphogen-regulated transcriptional network. Development 135:2489-2503. CrossRef Medline

Donnelly CJ, Willis DE, Xu M, Tep C, Jiang C, Yoo S, Schanen NC, KirnSafran CB, van Minnen J, English A, Yoon SO, Bassell GJ, Twiss JL (2011) Limited availability of ZBP1 restricts axonal mRNA localization and nerve regeneration capacity. EMBO J 30:4665-4677. CrossRef Medline

Fazeli A, Dickinson SL, Hermiston ML, Tighe RV, Steen RG, Small CG, Stoeckli ET, Keino-Masu K, Masu M, Rayburn H, Simons J, Bronson RT, Gordon JI, Tessier-Lavigne M, Weinberg RA (1997) Phenotype of mice lacking functional Deleted in colorectal cancer (Dec) gene. Nature 386: 796-804. CrossRef Medline

Gu W, Katz Z, Wu B, Park HY, Li D, Lin S, Wells AL, Singer RH (2012) Regulation of local expression of cell adhesion and motility-related $\mathrm{mR}$ NAs in breast cancer cells by IMP1/ZBP1. J Cell Sci 125:81-91. CrossRef Medline

Hansen TV, Hammer NA, Nielsen J, Madsen M, Dalbaeck C, Wewer UM, Christiansen J, Nielsen FC (2004) Dwarfism and impaired gut development in insulin-like growth factor II mRNA-binding protein 1-deficient mice. Mol Cell Biol 24:4448-4464. CrossRef Medline

Hüttelmaier S, Zenklusen D, Lederer M, Dictenberg J, Lorenz M, Meng X, Bassell GJ, Condeelis J, Singer RH (2005) Spatial regulation of $\beta$-actin translation by Src-dependent phosphorylation of ZBP1. Nature 438:512515. CrossRef Medline

Jung H, Yoon BC, Holt CE (2012) Axonal mRNA localization and local protein synthesis in nervous system assembly, maintenance and repair. Nat Rev Neurosci 13:308-324. CrossRef Medline

Kalous A, Stake JI, Yisraeli JK, Holt CE (2014) RNA-binding protein Vg1RBP regulates terminal arbor formation but not long-range axon navigation in the developing visual system. Dev Neurobiol 74:303-318. CrossRef Medline

Kennedy TE, Serafini T, de la Torre JR, Tessier-Lavigne M (1994) Netrins are diffusible chemotropic factors for commissural axons in the embryonic spinal cord. Cell 78:425-435. CrossRef Medline

Langlois SD, Morin S, Yam PT, Charron F (2010) Dissection and culture of commissural neurons from embryonic spinal cord. J Vis Exp 39: pii: 1773. CrossRef Medline

Leung KM, van Horck FP, Lin AC, Allison R, Standart N, Holt CE (2006) Asymmetrical $\beta$-actin mRNA translation in growth cones mediates attractive turning to netrin-1. Nat Neurosci 9:1247-1256. CrossRef Medline

Leung LC, Urbančič V, Baudet ML, Dwivedy A, Bayley TG, Lee AC, Harris WA, Holt CE (2013) Coupling of NF-protocadherin signaling to axon guidance by cue-induced translation. Nat Neurosci 16:166-173. CrossRef Medline

Li C, Sasaki Y, Takei K, Yamamoto H, Shouji M, Sugiyama Y, Kawakami T, Nakamura F, Yagi T, Ohshima T, Goshima Y (2004) Correlation between Semaphorin3A-induced facilitation of axonal transport and local activation of a translation initiation factor eukaryotic translation initiation factor 4E. J Neurosci 24:6161-6170. CrossRef Medline 
Luria V, Krawchuk D, Jessell TM, Laufer E, Kania A (2008) Specification of motor axon trajectory by Ephrin-B:EphB signaling: Symmetrical control of axonal patterning in the developing limb. Neuron 60:1039-1053. CrossRef Medline

Manns RP, Cook GM, Holt CE, Keynes RJ (2012) Differing Semaphorin 3A concentrations trigger distinct signaling mechanisms in growth cone collapse. J Neurosci 32:8554-8559. CrossRef Medline

Nédelec S, Peljto M, Shi P, Amoroso MW, Kam LC, Wichterle H (2012) Concentration-dependent requirement for local protein synthesis in motor neuron subtype-specific response to axon guidance cues. J Neurosci 32:1496-1506. CrossRef Medline

Okada A, Charron F, Morin S, Shin DS, Wong K, Fabre PJ, Tessier-Lavigne M, McConnell SK (2006) Boc is a receptor for sonic hedgehog in the guidance of commissural axons. Nature 444:369-373. CrossRef Medline

Preitner N, Quan J, Li X, Nielsen FC, Flanagan JG (2016) IMP2 axonal localization, RNA interactome, and function in development of axon trajectories. Development 143:2753-2759. CrossRef Medline

Roche FK, Marsick BM, Letourneau PC (2009) Protein synthesis in distal axons is not required for growth cone responses to guidance cues. J Neurosci 29:638-652. CrossRef Medline

Ross AF, Oleynikov Y, Kislauskis EH, Taneja KL, Singer RH (1997) Characterization of a beta-actin mRNA zipcode-binding protein. Mol Cell Biol 17:2158-2165. CrossRef Medline

Ruiz de Almodovar C, et al. (2011) VEGF mediates commissural axon chemoattraction through its receptor Flk1. Neuron 70:966-978. CrossRef Medline

Sasaki Y, Welshhans K, Wen Z, Yao J, Xu M, Goshima Y, Zheng JQ, Bassell GJ (2010) Phosphorylation of zipcode binding protein 1 Is required for Brain-derived neurotrophic factor signaling of local $\beta$-actin synthesis and growth cone turning. J Neurosci 30:9349-9358. CrossRef Medline

Serafini T, Kennedy TE, Galko MJ, Mirzayan C, Jessell TM, Tessier-Lavigne M (1994) The netrins define a family of axon outgrowth-promoting proteins homologous to C. elegans UNC-6. Cell 78:409-424. CrossRef Medline

Serafini T, Colamarino SA, Leonardo ED, Wang H, Beddington R, Skarnes WC, Tessier-Lavigne M (1996) Netrin-1 Is required for commissural axon guidance in the developing vertebrate nervous system. Cell 87:10011014. CrossRef Medline

Shigeoka T, Lu B, Holt CE (2013) RNA-based mechanisms underlying axon guidance. J Cell Biol 202:991-999. CrossRef Medline
Shigeoka T, Jung H, Jung J, Turner-Bridger B, Ohk J, Lin JQ, Amieux PS, Holt CE (2016) Dynamic axonal translation in developing and mature visual circuits. Cell 166:181-192. CrossRef Medline

Sloan TF, Qasaimeh MA, Juncker D, Yam PT, Charron F (2015) Integration of shallow gradients of Shh and Netrin-1 guides commissural axons. PLoS Biol 13:e1002119. CrossRef Medline

Spooner BS, Holladay CR (1981) Distribution of tubulin and actin in neurites and growth cones of differentiating nerve cells. Cell Motil 1:167-178. CrossRef Medline

Welshhans K, Bassell GJ (2011) Netrin-1-induced local $\beta$-actin synthesis and growth cone guidance requires zipcode binding protein 1. J Neurosci 31:9800-9813. CrossRef Medline

Wu B, Buxbaum AR, Katz ZB, Yoon YJ, Singer RH (2015) Quantifying protein-mRNA interactions in single live cells. Cell 162:211-220. CrossRef Medline

Xing L, Bassell GJ (2013) mRNA localization: an orchestration of assembly, traffic and synthesis. Traffic 14:2-14. CrossRef Medline

Yam PT, Charron F (2013) Signaling mechanisms of non-conventional axon guidance cues: the Shh, BMP and Wnt morphogens. Curr Opin Neurobiol 23:965-973. CrossRef Medline

Yam PT, Langlois SD, Morin S, Charron F (2009) Sonic hedgehog guides axons through a noncanonical, Src-family-kinase-dependent signaling pathway. Neuron 62:349-362. CrossRef Medline

Yam PT, Kent CB, Morin S, Farmer WT, Alchini R, Lepelletier L, Colman DR, Tessier-Lavigne M, Fournier AE, Charron F (2012) 14-3-3 proteins regulate a cell-intrinsic switch from Sonic hedgehog-mediated commissural axon attraction to repulsion after midline crossing. Neuron 76:735-749. CrossRef Medline

Yao J, Sasaki Y, Wen Z, Bassell GJ, Zheng JQ (2006) An essential role for $\beta$-actin mRNA localization and translation in $\mathrm{Ca} 2+$-dependent growth cone guidance. Nat Neurosci 9:1265-1273. CrossRef Medline

Zhang HL, Singer RH, Bassell GJ (1999) Neurotrophin regulation of $\beta$-actin mRNA and protein localization within growth cones. J Cell Biol 147:5970. CrossRef Medline

Zhang HL, Eom T, Oleynikov Y, Shenoy SM, Liebelt DA, Dictenberg JB, Singer RH, Bassell GJ (2001) Neurotrophin-induced transport of a $\beta$-actin mRNP complex increases $\beta$-actin levels and stimulates growth cone motility. Neuron 31:261-275. CrossRef Medline 